\title{
Cyclosporine-Induced Oxidative Stress and renal Dysfunction in Rat kidneys: A Possible Ameliorated Effect by Curcumin as an Antioxidant
}

\author{
Mohamed, I.A. Heibashy; Walaa, A.M. El-Nahrawy* \\ and Nashwa A. Zaki** \\ Biological Applications Department, Nuclear Research Center, Atomic \\ Energy Authority; *Zoology Department, Girl's Collage, Ain Shams \\ University; *Hepatology and Tropical Diseases Nation Institute, Cairo
}

\begin{abstract}
Curcumin (CMN) has been well studied due to its economic and medical importance. Traditional Egyptian Medicine claims the use of its powder against biliary disorders, anorexia, coryza, cough, diabetic wounds, hepatic disorder, rheumatism and sinusitis. The current study was designed to examine the possible beneficial effect of CMN in preventing the acute renal failure and related oxidative stress caused by chronic administration of cyclosporine (CsA) in rats. The study included two experiments, the first one was carried out to follow up the changes that could occur in kidney function as a result of cyclosporine (CsA) administration. Cyclosporine administration exerted significant $(P<0.01)$ elevation of serum urea, creatinine, potassium $(K)$, parathormone $(\mathrm{PTH})$, malondialdehyde $(\mathrm{MDA})$ and asymmetrical dimethylarginine (ADMA). Meanwhile, cyclosporine treatment exerted significant $(P<0.01)$ decline in the level of serum sodium ( $\mathrm{Na}$ ) and total nitric oxide (NO), the content of kidney reduced glutathione $(G S H)$ and the activities of glutathione peroxidase $\left(G_{p x}\right)$, catalase (CAT) and superoxide dismutase (SOD) as compared with their corresponding normal rats. In the second experiment, the nephritic rats were treated with curcumin and remarkable corrections were occurred in all previous parameters. Thus, the current investigation was designed to examine the possible beneficial effect of CMN in preventing the renal failure and related oxidative stress caused by administration of CsA in rats.
\end{abstract}

Key words: Cyclosporine - Curcumin - kidney function tests - Rats

\section{INTRODUCTION}

The aminoglycosides antibiotics are so named because they consist of two or more amino sugars joined in a glycosidic linkage to a central hexose nucleus. The incidence of renal dysfunction following aminoglycoside administration ranges from 5 to $26 \%^{(1,2)}$.

Cyclosporine A has been shown to enhance generation of hydrogen peroxide in vitro and enhances lipid peroxidation in vitro and in vivo. Antioxidants have been shown to be protective in cyclosporine A nephrotoxicity. Such collective body 
of evidence suggests an important role for reactive oxygen metabolites in toxic acute renal failure and may provide therapeutic opportunities of preventing or treating acute renal failure in humans ${ }^{(2-5)}$.

Cyclosporine (CsA) (formerly called cyclosporine A), a hydrophobic cyclic un decapeptide produced by the fungus Tolypocladium inflatum, can be considered the prototype of immunosuppressant that has revolutionized the management of allotransplantation $^{(6)}$. CsA combines low myelotoxicity with effectiveness in preventing allograft rejection and graft versus host disease as well as in the treatment of various autoimmune and ocular inflammatory diseases ${ }^{(7)}$. Nephrotoxicity and hypertension are the major adverse effects that often limit CsA treatment following solid organ transplantation and autoimmune diseases ${ }^{(8)}$. The functional changes caused by CsA are dose dependant and are usually reversible after shortterm CsA treatment ${ }^{(\mathbf{9})}$.

Cumulative data suggest a role for reactive oxygen metabolites as one of the postulated mechanisms in the pathogenesis of CsA nephrotoxicity. CsA results in enhanced generation of hydrogen peroxide in cultured hepatocytes ${ }^{(\mathbf{1 0})}$ and mesangial cells ${ }^{(\mathbf{1 1})}$. In vitro and in vivo studies indicate that CsA enhances lipid peroxidation, reduces renal microsomal NADPH cytochrome $\mathrm{P}_{450}$, and renal reduced/oxidized glutathione ratio (GSH/GSSG) in kidney cortex as well as renal microsomes and mitochondria ${ }^{(5,12)}$. Antioxidants such as $\alpha$-tocopherol, ascorbate, silibinin, lazaroid, propionyl carnitine and superoxide dismutase/catalase, have been shown to ameliorate cyclosporine-induced renal toxicity ${ }^{(10,}$ 13).

Current traditional Indian medicine claims the use of Curcuma longa L. (Zingiberaceae) powder against biliary disorders, anorexia, coryza, cough, diabetic wounds, hepatic disorder, rheumatism and sinusitis ${ }^{(14)}$. Curcumin (CMN) is a major component in curcuma/turmeric, being responsible for its biological actions. More and more studies now show that $\mathrm{CMN}$ exhibit anti-inflammatory ${ }^{(17)}$, antihuman immunodeficiency virus $^{(\mathbf{1 6 , 1 7})}$, anti-bacterial (18) and nematocidal activities ${ }^{(19)}$. Various in-vitro and invivo studies increasingly establish the antioxidant properties of CMN ${ }^{(20,21)}$. It is well documented that $\mathrm{CMN}$ scavenges superoxide anions (22), peroxynitrite radicals ${ }^{(23,24)}$ and quenches singlet oxygen ${ }^{(25)}$. CMN has also been shown to inhibit hydrogenperoxide-induced cell damage ${ }^{(21)}$.

Thus, the current study was designed to examine the possible beneficial effect of $\mathrm{CMN}$ in preventing the acute renal failure and related oxidative stress caused by chronic administration of CsA in rats.

\section{MATERIAL \& METHODS}

Fifty adult male albino rats Rattus rattus $(140 \pm 10 \mathrm{~g})$ were employed in the present study. They were housed in a well ventilated animal house and kept under the same managerial and environmental conditions. They were fed to appetite on a standard laboratory animal diet and fresh tap water was available at all times ${ }^{(\mathbf{2 6})}$. The animals were caged 
in wire bottom galvanized metal wall boxes.

The study included two experiments; the first one was carried out to follow up the changes that could occur in kidney function tests as a result of cyclosporine (CsA) treatment. To achieve that purpose, a comparison was carried out between a group of five normal control rats injected subcutaneous daily with olive oil for 21 days and other five animals were daily injected subcutaneous (s.c.) with cyclosporine (CsA) at a dose of $20 \mathrm{mg} / \mathrm{kg} /$ day dissolved in olive oil for the same period ${ }^{(2)}$.

In the second experiment, four comparisons were made between three groups of rats with renal toxicity induced by cyclosporine (CsA) administration, where the first group of animals (ten rats) was left without further treatment (recovery nephrotoxicated group). The second group of cyclosporine (CsA) toxicated rat (ten rats) was treated orally with $15 \mathrm{mg}$ curcumin $(\mathrm{CMN}) / \mathrm{kg}$ b.wt. The third group of cyclosporine (CsA) toxicated rat (ten rats) was CsA treated orally with $30 \mathrm{mg}$ curcumin $(\mathrm{CMN}) / \mathrm{kg}$ b.wt. The fourth group animal was non-treated and served as control animal group. All animal groups were divided into two intervals (two and four weeks and five rats in each interval).

Cyclosporine (CsA) was purchased from Sigma Chem. Co., St Louis, Mo. U.S.A. Commercial curcumin (CMN) was used. Biochemical analyses have been made in order to evaluate the possible ameliorating effect of curcumin $(\mathrm{CMN})$ on the kidney function at various intervals as a result of cyclosporine administration.

At the end of each experimental period, blood samples were collected from each group by decapitation killing. The contents of serum urea and creatinine, were assayed colorimetrically using commercial kits (Randox Ltd., Co. UK) ${ }^{(27,28)}$. Sodium $(\mathrm{Na})$ and potassium $(\mathrm{K})$ analysis were accomplished by emission flame photometry after suitable dilutions ${ }^{(29)}$. Serum parathormone (PTH) was assayed by radioimmunoassay kit using solid phase component (ICN Pharmaceuticals Co., USA) (30). Plasma ADMA ${ }^{(31)}$ and serum total nitric oxide ${ }^{(32)}$ and malondialdehyde (MDA) ${ }^{(33)}$ were assayed by ELISA technique using commercial kits (Oxis, Inc., USA).

After sacrifice, kidneys were obtained at the end of each experimental period and washed with saline solution $(0.9 \% \mathrm{Na} \mathrm{Cl})$. After washing, the kidneys were homogenized in ice-cold $0.25 \mathrm{M}$ sucrose containing $1 \mathrm{mM}$ diethylenetriamine penta-acetic acid $(1: 1 \mathrm{w} / \mathrm{v})$. Each sample was then centrifuged for $20 \mathrm{~min}$ at $20,000 \mathrm{~g}$ and $4^{\circ} \mathrm{C}$. The supernatant was aspirated for measuring the content of reduced GSH (34) and the activities of glutathione peroxidase $\left(\mathrm{G}_{\mathrm{PX}}\right)^{(\mathbf{3 5})}$, catalase $(\mathrm{CAT})^{(\mathbf{3 6})}$ and superoxide dismutase $(\mathrm{SOD})^{(37)}$ by ELISA technique using commercial kits (IBL Gesellschaft, Hamburg, Germany).

Data were statistically analyzed using Student " $t$ " test in the first experimental $^{(38)}$. Moreover, two way analysis of variance (ANOVA) followed by Duncan's multiple range test in the second experiment ${ }^{(39)}$. 


\section{RESULTS \& DISCUSSION}

In the current study, rat was used as an animal model for induction of acute renal failure by cyclosporine injection at a dose equivalent to that used clinically in $\operatorname{man}^{(2)}$. Tirkey et al., found that cyclosporine injection (20 $\mathrm{mg} / \mathrm{kg}$ b.wt for 21 days) developed injury in the proximal tubular epithelial cells of kidney that caused acute renal failure. Injection of rats with cyclosporine ( $30 \mathrm{mg} / \mathrm{kg}$ b.wt for 14 days) created degenerative nephropathy $^{(\mathbf{4 0})}$.

Cyclosporine is used for the prevention of rejection of kidney ${ }^{(41)}$, liver ${ }^{(\mathbf{4 2})}$ or heart allografts ${ }^{(\mathbf{4 3})}$. So, cyclosporine is used to prolong graft survival of allogenic renal transplants ${ }^{(\mathbf{4 4 , 4 5})}$. Therapy with cyclosporine alone has achieved graft survival rates ranging from $71-91 \% 1$ year after renal transplantation ${ }^{(46)}$. In a retrospective study, patients and graft survival rates were 86 and $70 \%$, respectively, 4 years after transplantation in cyclosporine-treated patients $^{(\mathbf{4 5})}$.

The most frequent and clinically important adverse effect of cyclosporine is nephrotoxicity ${ }^{(41)}$. Nephrotoxic effects (usually manifested as increased BUN and serum creatinine concentrations) of cyclosporine have been observed in $25-32,38$, or $37 \%$ of patients receiving the drug for kidney, heart, or liver allografts, respectively ${ }^{(45)}$. Elevations of BUN and serum creatinine concentrations resulting from cyclosporine therapy appears to be dose related, may be associated with high concentrations of the drug, and are usually reversible upon discontinuance of the drug (44, 45). Clinical manifestations of cyclosporine-induced nephrotoxicity may include fluid retention, dependent edema, and, in some cases, a hyperchloremic, hyperkalemic metabolic acidosis ${ }^{(47,48)}$. The risk of cyclosporine-induced nephrotoxicity may be increased in patients receiving other potentially nephrotoxic agents. Mild cyclosporine-induced nephrotoxicity generally occurs within 2 to 3 months after transplantation. Although some decline from preoperative levels generally occurs in patients with mild nephrotoxicity, the BUN and serum creatinine concentrations reportedly become stabilized in the range of 35-45 $\mathrm{mg} / \mathrm{dL}$ and $2-2.5 \mathrm{mg} / \mathrm{dL}$, respectively, in these patients; however, these elevations often respond to dosage reduction. In some patients, more severe nephrotoxic effects have been observed early after transplantation and have been characterized by rapid increases in BUN and serum creatinine concentrations; these elevations usually respond to dosage reduction $^{(47,48)}$.

In the current investigation, acute renal failure was characterized by disorders in some biochemical parameters in cyclosporine (CsA) treated rats. Serum urea and creatinine increased to about $210 \%$ and $230 \%$ respectively over their corresponding values in control group (Table 1). Similar greater serum urea over control rats was obtained ${ }^{(2)}$ in a doserelated fashion in rats treated with graded doses of cyclosporine (CsA). Accordingly, these changes reflected the severity of renal insufficiency. It is possible that all these biochemical 
alterations occurred in association with the sudden fall in glomerular filtration rates because of the majority of administered cyclosporine (CsA) dose enters specifically the proximal tubular epithelial cells, binds to anionic phospholipids in the target cells inducing abnormalities in the function and metabolism of multiple intracellular membranes and orgranelles $^{(49,50,51)}$. Animals with cyclosporine (CsA) nephrotoxicity showed increased lipid peroxidation in the kidney cortex ${ }^{(2,51,52,53)}$.

Table (1): Effects of cyclosporine administration on some physiological and biochemical parameters in rats

\begin{tabular}{|c|c|c|}
\hline Parameters & $\begin{array}{l}\text { Control group } \\
\mathrm{n}=5 \text { rats }\end{array}$ & $\begin{array}{l}\text { cyclosporone } \\
\text { group } \\
\text { n = 5 rats }\end{array}$ \\
\hline Urea (mg/dL) & $16.347 \pm 0.496$ & $34.112 \pm 0.925^{*}$ \\
\hline Creatinine (mg/dL) & $0.482 \pm 0.007$ & $1.104 \pm 0.016^{*}$ \\
\hline Sodium (Na) (meq/L) & $132.913 \pm 1.965$ & $124.627 \pm 1.783^{*}$ \\
\hline Potassium (K) (meq/L) & $4.037 \pm 0.184$ & $5.114 \pm 0.261 *$ \\
\hline Parathormone (PTH) (ng/ml) & $10.516 \pm 0.592$ & $17.815 \pm 0.883^{*}$ \\
\hline ADMA $(\mu \mathrm{mol} / \mathrm{L})$ & $1.137 \pm 0.079$ & $2.842 \pm 0.096^{*}$ \\
\hline TNO $(\mu \mathrm{mol} / \mathrm{L})$ & $59.41 \pm 1.217$ & $30.916 \pm 1.031 *$ \\
\hline MDA (nmol /dL) & $0.537 \pm 0.009$ & $0.921 \pm 0.018^{*}$ \\
\hline GSH (mg/g protein) & $11.142 \pm 0.683$ & $7.056 \pm 0.497 *$ \\
\hline Gpx ( $\mu \mathrm{mol}$ GSH utilized/min/g protein) & $23.351 \pm 0.947$ & $16.682 \pm 0.782 *$ \\
\hline CAT (nmol/60 $\mathrm{min} / \mathrm{mg}$ protein) & $42.573 \pm 1.108$ & $35.011 \pm 0.926^{*}$ \\
\hline SOD (Nu/60 $\mathrm{min} / \mathrm{mg}$ protein) & $5.104 \pm 0.213$ & $3.825 \pm 0.187^{*}$ \\
\hline
\end{tabular}

- Values are expressed as mean $\pm S E$.

$-{ }^{*}$ Means a significant $(P<0.001)$.

Electrolytes in serum was disturbed remarkably $(\mathrm{P}<0.05)$ in cyclosporine $(\mathrm{CsA})$ treated rats as compared with untreated animals. As shown in table (1), lower value of serum $\mathrm{Na}^{+}$in cyclosporine (CsA) treated rats than controls indicates inability of kidney to conserve sodium and chloride. Hemodilution too may be involved in the fall of $\mathrm{Na}^{+}$value via excess of water intake and/or increased production of endogenous water. In turn, the reversed increase of $\mathrm{K}^{+}$appeared to be due to reduced excretion of $\mathrm{K}^{+}$aggravated by leakage of intracellular $\mathrm{K}^{+}$into blood stream as a result of cyclosporine (CsA) induced lesions in renal tubular epithelium $^{\text {(54- 57). }}$.

Moreover, the exact mechanism of CsA-induced hypertension and nephrotoxicity remain obscure but several studies suggest that a defect in intracellular calcium handling ${ }^{(57)}$, magnesium deficiency ${ }^{(56)}$ oxidative stress $^{(\mathbf{5 8 , 5 9 )}}$ and nitric oxide (NO) system $^{(\mathbf{6 0})}$ are involved. So, acute renal failure due to CsA is widely attributed 
to the generation of reactive oxygen species (ROS) by CsA.

The current study revealed that chronic administration of CsA for 21 days caused a marked impairment of renal function along with significant oxidative stress in the kidneys causing a significant decline in the content of kidney GSH and the activities of kidney $\mathrm{G}_{\mathrm{px}}$, CAT and SOD (Table $1)^{(2,21,61)}$. These finding could be attributed these results to the increase of lipid peroxidation and free radicals production.

It has been reported that binding of pimonidazole, a hypoxia marker in the kidneys, was increased nearly three fold by CsA, indicating marked tissue hypoxia ${ }^{(61)}$. Moreover, free radicals in the urine were increased dramatically after CsA treatment ${ }^{(62,63)}$. It is also known that CsA increases renal nerve activity resulting in vasoconstriction in the kidney ${ }^{(40)}$. In addition, CsA causes vasoconstriction directly in isolated renal

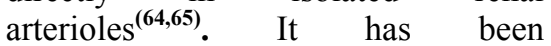
demonstrated that CsA blocks mitochondrial calcium $\left(\mathrm{Ca}^{+2}\right)$ release, inducing a drastic enhancement in intracellular free $\mathrm{Ca}^{+2}$, which could account for the vasoconstrictive effect of CsA ${ }^{(66,67)}$. These alterations could theoretically lead to a classical hypoxia-reoxygenation injury involving oxygen free radicals. In addition, ROS could be derived directly from CsA or during its metabolism by the CYP 450 system ${ }^{\text {(11). }}$. It has been demonstrated that cyclosporine increased level of superoxide $\left(\mathrm{O}_{2}{ }^{-}\right)$in endothelial and mesangial cells ${ }^{(5)}$. Studies show that CsA-induced local production of hydroxyl radical, a highly active and detrimental radical that plays an important role in CsA nephrotoxicity ${ }^{(68)}$.

Couple of studies suggested that CsA induces apoptosis characterized by internucleosomal DNA cleavage due to endonuclease activation, chromatin condensation, and apoptotic bodies in hematopoietic cells ${ }^{(69)}$. Because oxidants are capable of inducing apoptosis in various types of cells $^{(70)}$, including renal tubular epithelial cells ${ }^{(71)}$, it is conceivable that reactive oxygen metabolites may play a role in apoptotic mechanism of CsA-induced nephrotoxicity.

The current investigation revealed that chronic administration of CsA for 21 days caused a marked impairment of renal function along with significant oxidative stress in the kidneys. Curcumin significantly and dose-dependently improved creatinine and urea levels, and decreased the elevated levels of serum creatinine and urea. Earlier studies have also shown that $\mathrm{CMN}$ pretreatment decreases ischemia-reperfusion induced rise in serum creatinine levels in kidney ${ }^{(72)}$. Chronic administration of CsA also produced oxidative stress and increased the lipid peroxidation in kidneys as is seen by the serum MDA level. That effect of CsA was again ameliorated by CMN treatment and is in line with various previous reports, which showed that CMN decreases lipid peroxidation possibly by its antioxidant mechanism ${ }^{(73)}$. Oxidative stress could promote the formation of a variety of vasoactive mediators that can affect renal function directly by causing renal vasoconstriction or decreasing the glomerular capillary ultrafiltration coefficient; and thus 
reducing glomerular filtration rate ${ }^{(74)}$. Thus, the attenuation of lipid peroxidation in CsA-treated rats by CMN provides a convincing evidence for the involvement of ROS in CsAinduced lipid peroxidation. Rukkumani et al. ${ }^{(75)}$ reported protective effect of CMN on circulating lipids in plasma and lipid peroxidation products in alcohol and polyunsaturated fatty acid-induced toxicity. In-vitro, Somasundaram et al. ${ }^{\text {(76) }}$ supported the hypothesis that $\mathrm{CMN}$ inhibits free radical induced apoptosis in cell lines.

From the data presented in table (2), it is obvious that late $\mathrm{CMN}$ administration proved to have some ameliorating effects against undesirable changes in kidney function following cyclosporine (CsA) injection for 21 days. With the progress of time after the drug was discontinued, serum urea, creatinine, $\mathrm{K}, \mathrm{PTH}, \mathrm{ADMA}$ and MDA decreased $(\mathrm{P}<0.05)$ significantly during the treatment with $\mathrm{CMN}$ as compared with nephrotoxic group, although the levels of all those variables were still significantly $(\mathrm{P}<0.05)$ higher than saline injected rats (controls). On other hand, serum $\mathrm{Na}$ and total nitric oxide (NO) increased $\quad(\mathrm{P}<0.05)$ significantly during the treatment with CMN as compared with nephrotoxic animal group (Table 2). These increments were still not reached to that corresponding normal control rat group.

More and more studies now established the ability of CMN to mainly eliminate the hydroxyl radical, superoxide radical $^{(77)}$, singlet oxygen $^{(79)}$, nitrogen dioxide ${ }^{(\mathbf{8 0})}$ and $\mathrm{NO}^{(78)}$.

It has also been demonstrated that $\mathrm{CMN}$ inhibits the generation of the superoxide radical ${ }^{\mathbf{8 2})}$. In the current study, CsA administration caused marked deterioration of endogenous antioxidant profile as evidenced by decrease in SOD and CAT activities, an effect which was effectively reversed by $\mathrm{CMN}$ treatment ${ }^{\text {(22) }}$. CMN manganese complex and acetylcurcumin manganese complex, low molecular weight synthetic compounds, showed much greater SOD activity and an inhibitory effect on lipid peroxidation.

Further, GSH a major non-protein thiol in living organisms plays a crucial role in coordinating the body's antioxidant defense processes. Results in the current study indicated that CsA administration drastically lowered the levels of GSH in the kidney. Improvement of renal GSH levels in $\mathrm{CMN}$ treated rats in comparison to CsA administered rats further demonstrates the antioxidative effect of CMN. CMN has been shown to increase the levels of glutathione reductase in ischemic brains of rats as well as alveolar and human leukemia cell $^{(2,21,57)}$. The prolonged treatment of $\mathrm{CMN}$ also improved the levels of two key antioxidant enzymes SOD and catalase (CAT) in CsA administered rats. 
Table (2): Effect of curcumin $(15 \& 30 \mathrm{mg} / \mathrm{B} \mathrm{Wt})$ treatment on kidney function tests in cyclosporine-nephrotoxic rats

\begin{tabular}{|c|c|c|c|c|c|}
\hline \multicolumn{2}{|c|}{$\begin{array}{ll}\text { Groups } & \text { Parameters }\end{array}$} & \multirow{2}{*}{$\begin{array}{l}\text { Control } \\
16.421 \pm 0.489^{\mathrm{a}}\end{array}$} & \multirow{2}{*}{$\begin{array}{l}\text { Recovery } \\
33.102 \pm 0.917^{\mathrm{b}}\end{array}$} & \multirow{2}{*}{$\begin{array}{l}\text { Cyclosporine } \\
+ \text { Curcumin } \\
\mathbf{1 5} \mathbf{~ m g} \\
30.561 \pm 0.832^{\mathrm{d}}\end{array}$} & \multirow{2}{*}{$\begin{array}{l}\text { Cyclosporine } \\
+ \text { Curcumin } \\
\text { 30 } \mathbf{~ m g} \\
28.473 \pm 0.792^{\mathrm{e}}\end{array}$} \\
\hline Urea (mg/dL) & $\begin{array}{l}15 \text { days } \\
n=5\end{array}$ & & & & \\
\hline & $\begin{array}{l}30 \text { days } \\
n=5\end{array}$ & $16.407 \pm 0.489^{\mathrm{a}}$ & $31.354 \pm \cdot .869^{\mathrm{c}}$ & $28.162 \pm 0.764^{\mathrm{e}}$ & $21.958 \pm 0.711^{\mathrm{f}}$ \\
\hline \multirow[t]{2}{*}{$\begin{array}{l}\text { Creatinine } \\
(\mathrm{mg} / \mathrm{dL})\end{array}$} & $\begin{array}{l}15 \text { days } \\
n=5\end{array}$ & $0.484 \pm 0.007^{\mathrm{a}}$ & $1.073 \pm 0.017^{b}$ & $0.892 \pm 0.013^{\mathrm{c}}$ & $0.802 \pm 0.012^{\mathrm{d}}$ \\
\hline & $\begin{array}{l}30 \text { days } \\
n=5\end{array}$ & $0.484 \pm 0.006^{\mathrm{a}}$ & $1.008 \pm 0.014^{b}$ & $0.795 \pm 0.012^{d}$ & $0.653 \pm 0.011^{\mathrm{e}}$ \\
\hline \multirow[t]{2}{*}{$\begin{array}{l}\text { Sodium (Na) } \\
(\mathrm{meq} / \mathrm{L})\end{array}$} & $\begin{array}{l}15 \text { days } \\
n=5\end{array}$ & $132.871 \pm 1.894^{\mathrm{a}}$ & $125.712 \pm 1.692^{b}$ & $126.983 \pm 1.749^{c}$ & $129.237 \pm 1.814^{\mathrm{d}}$ \\
\hline & $\begin{array}{l}30 \text { days } \\
n=5\end{array}$ & $133.145 \pm 1.971^{\mathrm{a}}$ & $125.946 \pm 1.571^{b}$ & $129.052 \pm 1.802^{d}$ & $132.152 \pm 1.853^{\mathrm{a}}$ \\
\hline \multirow[t]{2}{*}{$\begin{array}{l}\text { Potassium (K) } \\
(\mathrm{meq} / \mathrm{L})\end{array}$} & $\begin{array}{l}15 \text { days } \\
n=5\end{array}$ & $4.112 \pm 0.187^{\mathrm{a}}$ & $5.092 \pm 0.257^{b}$ & $4.639 \pm 0.237^{\mathrm{c}}$ & $4.412 \pm 0.213^{\mathrm{d}}$ \\
\hline & $\begin{array}{l}30 \text { days } \\
n=5\end{array}$ & $4.103 \pm 0.185^{\mathrm{a}}$ & $5.011 \pm 0.258^{b}$ & $4.405 \pm 0.219^{d}$ & $4.121 \pm 0.197^{\mathrm{a}}$ \\
\hline \multirow[t]{2}{*}{$\begin{array}{l}\text { Parathormone } \\
\text { (PTH) }\end{array}$} & $\begin{array}{l}15 \text { days } \\
n=5\end{array}$ & $10.547 \pm 0.587^{\mathrm{a}}$ & $17.564 \pm 0.856^{b}$ & $15.932 \pm 0.749^{\mathrm{c}}$ & $14.567 \pm 0.712^{\mathrm{d}}$ \\
\hline & $\begin{array}{l}30 \text { days } \\
n=5\end{array}$ & $10.621 \pm 0.590^{\mathrm{a}}$ & $17.439 \pm 0.868^{b}$ & $13.037 \pm 0.663^{\mathrm{e}}$ & $12.108 \pm 0.641^{\mathrm{f}}$ \\
\hline \multirow[t]{2}{*}{$\begin{array}{l}\text { ADMA } \\
(\mu \mathrm{mol} / \mathrm{L})\end{array}$} & $\begin{array}{l}15 \text { days } \\
n=5\end{array}$ & $1.142 \pm 0.082^{\mathrm{a}}$ & $2.715 \pm 0.093^{b}$ & $2.441 \pm 0.085^{\mathrm{c}}$ & $2.011 \pm 0.081^{d}$ \\
\hline & $\begin{array}{l}30 \text { days } \\
n=5\end{array}$ & $1.139 \pm 0.082^{\mathrm{a}}$ & $2.436 \pm 0.087^{\mathrm{c}}$ & $1.983 \pm 0.079^{\mathrm{d}}$ & $1.502 \pm 0.083^{\mathrm{e}}$ \\
\hline \multirow[t]{2}{*}{$\begin{array}{l}\text { TNO } \\
(\mu \mathrm{mol} / \mathrm{L})\end{array}$} & $\begin{array}{l}15 \text { days } \\
n=5\end{array}$ & $58.971 \pm 1.188^{\mathrm{a}}$ & $34.042 \pm 1.141^{b}$ & $38.899 \pm 1.127^{\mathrm{c}}$ & $42.004 \pm 1.159^{\mathrm{d}}$ \\
\hline & $\begin{array}{l}30 \text { days } \\
n=5\end{array}$ & $59.156 \pm 1.197^{\mathrm{a}}$ & $39.117 \pm 1.032^{\mathrm{c}}$ & $44.769 \pm 1.162^{\mathrm{e}}$ & $49.537 \pm 1.194^{\mathrm{f}}$ \\
\hline
\end{tabular}

- Values are expressed as mean $\pm S E$.

${ }_{-}^{a, b, c, d, e, f}$ Means with a common subscript within an each parameter are not significantly different $(P>0.05)$.

Peroxynitrite anions have been generated by the reaction of nitric oxide with superoxide anion. These peroxynitrite anions oxidize biomolecules, which finally leads to lipid peroxidation and tubular cell damage ${ }^{(77,78)}$. Large amounts of nitric oxide can lead to the depletion of cellular ATP which can inactivate enzymes that contain iron-sulfur clusters, such enzymes involved in mitochondrial electron transport ${ }^{(\mathbf{8 3})}$. Nitrosylation of sulfhydryl groups or tyrosine residues in proteins may impair the functional properties of these proteins. Nitric oxide damages DNA, and this in turn, stimulates the DNA repair enzyme poly-ADP-ribose synthetase $^{(\mathbf{8 5})}$. Studies done by Amore et al. $^{(\mathbf{8 4})}$ demonstrated that CsA 
induces apoptosis in various renal cell lines, and this effect is mediated by the induction of iNOS. In line with studies where $\mathrm{CMN}$ is reported to inhibit iNOS gene expression in isolated $\mathrm{BALB} / \mathrm{c}$ mouse peritoneal macrophages and also in the livers of lipopolysaccharide injected mice ${ }^{(85)}$. The current study showed that CsAinduced nitrosative stress was significantly and dose dependently attenuated by CMN. Sumanont et al., studied the effect of $\mathrm{CMN}$ and its analogues on peroxynitrite anions scavenging activity in vitro using sodium nitroprusside (SNP) generating nitric oxide system. All compounds effectively reduced the generation of NO radicals in a dose dependent manner. It is also known that ROS mediates peroxidation of lipid structures of the tissue, resulting in subcellular damage, as observed in histopathological examination ${ }^{(\mathbf{2 4 , 8 5})}$.

Table (3): Effect of curcumin (15 \& $30 \mathrm{mg} / \mathrm{B} \mathrm{Wt})$ treatment on serum malondialdehyde and kidney GSH content \& $G_{p x}$, CAT and SOD activities in cyclosporine-nephrotoxic rats

\begin{tabular}{|c|c|c|c|c|c|}
\hline \multicolumn{2}{|c|}{ Groups $\quad$ Parameters } & \multirow{2}{*}{$\begin{array}{l}\text { Control } \\
0.539 \pm 0.009^{\mathrm{a}}\end{array}$} & \multirow{2}{*}{\begin{tabular}{|l} 
Recovery \\
$0.862 \pm 0.017^{b}$
\end{tabular}} & \multirow{2}{*}{\begin{tabular}{|l|}
$\begin{array}{l}\text { Cyclosporine } \\
+ \text { Curcumin } \\
\text { 15 mg }\end{array}$ \\
$0.761 \pm 0.016^{\mathrm{c}}$ \\
\end{tabular}} & \multirow{2}{*}{\begin{tabular}{|l|}
$\begin{array}{l}\text { Cyclosporine } \\
\text { Curcumin } \\
\text { 30 } \mathbf{~ m g}\end{array}$ \\
$\cdot .652 \pm 0.012^{\mathrm{d}}$
\end{tabular}} \\
\hline $\begin{array}{l}\text { MDA } \\
(\mathbf{n m o l} / \mathbf{d L})\end{array}$ & $\begin{array}{l}15 \text { days } \\
n=5\end{array}$ & & & & \\
\hline & $\begin{array}{l}30 \text { days } \\
n=5\end{array}$ & $0.537 \pm 0.009^{a}$ & $0.759 \pm 0.015^{\mathrm{c}}$ & $0.703 \pm 0.014^{\mathrm{e}}$ & $0.589 \pm 0.013^{f}$ \\
\hline \multirow[t]{2}{*}{$\begin{array}{l}\text { GSH } \\
\text { (mg/g protein) }\end{array}$} & $\begin{array}{l}15 \text { days } \\
n=5\end{array}$ & $11.211 \pm 0.702^{\mathrm{a}}$ & $7.911 \pm 0.512^{b}$ & $8.802 \pm 0.519^{c}$ & $9.401 \pm 0.557^{\mathrm{d}}$ \\
\hline & $\begin{array}{l}30 \text { days } \\
n=5\end{array}$ & $11.189 \pm 0.694^{\mathrm{a}}$ & $8.795 \pm 0.527^{\mathrm{c}}$ & $9.392 \pm 0.568^{d}$ & $10.378 \pm 0.632^{\mathrm{e}}$ \\
\hline \multirow{2}{*}{$\begin{array}{l}\text { Gpx } \\
(\mu \mathrm{mol} \text { GSH } \\
\text { utilized/min/g } \\
\text { protein })\end{array}$} & $\begin{array}{l}15 \text { days } \\
n=5\end{array}$ & $23.671 \pm 0.918^{\mathrm{a}}$ & $17.549 \pm 0.803^{b}$ & $19.562 \pm 0.856^{\mathrm{d}}$ & $20.493 \pm 0.917^{\mathrm{e}}$ \\
\hline & $\begin{array}{l}30 \text { days } \\
n=5\end{array}$ & $23.958 \pm 0.932^{\mathrm{a}}$ & $18.827 \pm 0.798^{\mathrm{c}}$ & $21.917 \pm 0.902^{f}$ & $23.714 \pm 0.898^{\mathrm{a}}$ \\
\hline \multirow{2}{*}{$\begin{array}{l}\text { CAT } \\
\text { (nmol/60 min/ } \\
\text { mg protein) }\end{array}$} & $\begin{array}{l}15 \text { days } \\
n=5\end{array}$ & $42.398 \pm 1.112^{\mathrm{a}}$ & $36.817 \pm 1.032^{\mathrm{c}}$ & $38.117 \pm 1.105^{\mathrm{c}}$ & $39.627 \pm 1.176^{\mathrm{d}}$ \\
\hline & $\begin{array}{l}30 \text { days } \\
n=5\end{array}$ & $42.711 \pm 1.136^{\mathrm{a}}$ & $38.032 \pm 1.032^{b}$ & $40.718 \pm 1.148^{\mathrm{e}}$ & $42.451 \pm 1.213^{\mathrm{a}}$ \\
\hline \multirow{2}{*}{$\begin{array}{l}\text { SOD } \\
\text { (Nu/60 } \\
\text { min/mg } \\
\text { protein) }\end{array}$} & $\begin{array}{l}15 \text { days } \\
n=5\end{array}$ & $5.113 \pm 0.221^{\mathrm{a}}$ & $3.917 \pm 0.192^{b}$ & $4.539 \pm 0.201^{\mathrm{d}}$ & $4.792 \pm 0.198^{\mathrm{e}}$ \\
\hline & $\begin{array}{l}\mathbf{3 0} \text { days } \\
n=5\end{array}$ & $5.122 \pm 0.218^{\mathrm{a}}$ & $4.202 \pm 0.189^{\mathrm{c}}$ & $4.917 \pm 0.211^{f}$ & $5.117 \pm 0.226^{\mathrm{a}}$ \\
\hline
\end{tabular}


In conclusion, this study demonstrated that $\mathrm{CMN}$ through its marked antioxidant activity coupled with favorable hemodynamic effects salvages CsA nephrotoxicity depending on the dose and time of treatment.

\section{REFERENCES}

1. Korzets, Z.; Pomeranz, A.; Golan, E. and Bernheim,J. (1997): Pefloxacin in adriamycin induced nephrotic syndrome in the rat. Nephrol. Dial. Transplant. 12(2): 286-8.

2. Tirkey, N.; Kaur, G.; Vij, G. and Chopra, K. (2005). Curcumin, a diferuloylmethane, attenuates cyclosporine-induced renal dysfunction and oxidative stress in rat kidneys. BMC Pharmacology. 5:15-28

3. Heibashy, M.I.A. and AbdelMoneim, A.E. (1999): Kidney and liver function tests after late dimethyl sulfoxide (DMSO) administration in rats with gentamicin induced acute renal failure. J. Egypt. Ger. Soc. Zool., 30 (A): $35-48$.

4. Heibashy, M.I.A. and BadieBakshwan, S. A. (1999): The harmful effects of adriamycin on testicular function of rats and the therapeutic or protective role of taurine. Egypt. J. Med. Sci., 20 (2): $613-631$.

5. Perez de Lema, G.; ArribasGomez, I.; Ruiz-Gines, J.A.; de Arriba, G.; Prieto, A.; Rodriguez-Puyol, D. and Rodriguez-Puyol, M.(1997): Reactive oxygen species mediate the effects of cyclosporine A on human cultured mesangial cells. Transplant. Proc., 29(1-2):12411243.

6. Buurman, W.A.; Daemen, A.J.; van der Linden, C.J. and Kootstra, G. (1987): Clinically used concentrations of cyclosporine A only partially inhibit interferon-gamma production by activated $\mathrm{T}$ lymphocytes. Transplant Proc, 19(1 Pt 2):1193.

7. Kahan, B.D (1989): Cyclosporine. N. Engl. J. Med ., 321(25):1725-1738

8. Mason, J. (1990): Pharmacology of cyclosporine (sandimmune). VII. Pathophysiology and toxicology of cyclosporine in humans and animals. Pharmacol. Rev., 41(3):423-434.

9. Remuzzi, G.and Perico, N. (1995): Cyclosporine-induced renal dysfunction in experimental animals and humans. Kid. Int.,52 (Suppl .,):S70-4.

10. Wolf, A.; Clemann, N.; Frieauff, W.; Ryffel, B.and Cordier, A. (1994): Role of reactive oxygen formation in the cyclosporin-A-mediated impairment of renal functions. Transplant Proc., 26(5):29022907.

11. Ahmed, S.S.; Napoli, K.L.; Strobel, H.W. (1995): Oxygen radical formation during cytochrome P450-catalyzed cyclosporine metabolism in rat and human liver microsomes at varying hydrogen ion concentrations. Mol .Cell Biochem ., 151(2):131-140.

12. Walker, G.; Kunz, D., Pignat, W.; Wiesenberg, I.; Van den 
Bosch, H. and Pfeilschifte, J. (1996): Tetranactin inhibits interleukin 1 beta and cAMP induction of group II phospholipase A2 in rat renal mesangial cells. Eur. J. Pharmacol ., 306(1-3):265-270.

13. Longoni, B.; Giovanni, L.; Migliori, M.; Bertelli, A.A and Bertelli, A. (1999): Cyclosporine-induced lipid peroxidation and propionyl carnitine protective effect. Int. J. Tissue React., 21(1):7-11.

14. Ammon, H.P. and Wahl, M.A. (1991): Pharmacology of Curcuma longa. Planta Med., 57(1):1-7.

15. Joe, B. and Lokesh, B.R. (1997): Effect of curcumin and capsaicin on arachidonic acid metabolism and lysosomal enzyme secretion by rat peritoneal macrophages. Lipids. 32(11):1173-1180.

16. De Clercq, E. (2000): Current lead natural products for the chemotherapy of human immunodeficiency virus (HIV) infection. Med. Res. Rev., 20(5):323-349.

17. Taher, M.M.; Lammering, G.; Hershe, C. and Valerie, K.: Curcumin inhibits ultraviolet light induced human immunodeficiency virus gene expression. Mol. Cell Biochem., 254(1-2):289-297.

18. Pal, A. and Pal, A. K. (2000): Studies on the genotoxicity of turmeric extracts in bacterial system .Int .J. Antimicrob. Agents., 16(4):415-417.

19. Jurgens, T.M.; Frazier, E.G.; Schaeffer, J.M.; Jones, T.E.;
Zink, D.L, Borris, R.P.; Nanakorn, W.; Beck, H.T.and Balick, M.J. (1994): Novel nematocidal agents from Curcuma comosa. J. Nat. Prod., 57(2):230-235.

20. Balasubramanyam, M.; Koteswari, A.A.; Kumar, R.S.; Monickaraj, S.F., Maheswari, J.U. and Mohan, V. (2003): Curcumin-induced inhibition of cellular reactive oxygen species generation: novel therapeutic implications. J Biosci.,28(6):715721.

21. Biswas, S.K.; McClure, D., Jimenez, L.A.; Megson, I.L. and Rahman, I. (2005): Curcumin induces glutathione biosynthesis and inhibits NFkappa-B activation and interleukin-8 release in alveolar epithelial cells: mechanism of free radical scavenging activity. Antioxid. Redox Signal., 7(12):32-41.

22. Vajragupta,

;Boonchoong,P.;Watanabe,H;T ohda,M.;Kummasud,N. and Sumanont, Y.(2003): Manganese complexes of curcumin and its derivatives: evaluation for the radical scavenging ability and neuroprotective activity. Free Radic .Biol .Med ., 35(12):16321644

23. Kim, J.E.; Kim, A.R.; Chung, H.Y.; Han, S.Y.; Kim, B.S.and Choi, J.S. (2003): In vitro peroxynitrite scavenging activity of diarylheptanoids from Curcuma longa. Phytother. Res., 17(5):481-484.

24. Sumanont, Y.; Murakami, Y.; Tohda, M.; Vajragupta, O.; 
Matsumoto, K. and Watanabe, H. (2004): Evaluation of the nitric oxide radical scavenging activity of manganese complexes of curcumin and its derivative. Biol. Pharm. Bull., 27(2):170173.

25. Das, K.C. and Das, C.K. (2002): Curcumin (diferuloylmethane), a singlet oxygen ((1)O(2)) quencher .Biochem Biophys Res Commun., 295(1):62-66.

26. NRC National Research Counal (1977): Nutrient requirements of domestic animals, nutrient requirements of rat. National Academy of Science, Washington , DC, U.S.A.

27. Fawcett, J.K. and Scott, J. (1960): Determination of blood urea using the berthelot reaction. J. Clin. Path., 13:156-162.

28. Seeling, F. and Wust, T. (1969): Modified methodology determination of creatinine. Z. Ernaehryg Swiss., 2(4): 169-176.

29. Dean, J. A. (1960): In: "Flame Photometry". $1^{\text {st }}$ ed. Mc-GrawHill Book Co. New York.

30. Rizzoli, R.; Vadas, L. and Bonjour, J.P. (1990): Determination of circulating parathyroid hormone. Nucl Med Biol.; 17 (7): 645 - 650.

31. Schulze, F.; Wesemann. R.; Schwedhelm, E.; Sydow, K.; Albsmeier. J.; Cooke, J.P. and Boger, R.H. (2004): Determination of asymmetric dimethylarginine (ADMA) using a novel ELISA assay. Clin. Chem. Lab. Med., 42(12): 137783.

32. Nine, R.W.; Darbyshire, J.E. and Saavedra, J.E. (1995): A new method for the determination of nitric oxide concentration in neutral aquase solution. Method. 7:48-54.

33. Pedeson, M.A.; Scott, C.S. and William, A. B. (1990): Evaluation of lipid peroxidation in inflammatory patients. Ann. NY Acad. Sci., 559: 45-62.

34. Baker, M.A.; Cerniglia, G.J. and Zaman, A. (1990): Microtiter plate assay for the measurement of glutathione and glutathione disulfide in large numbers of biological samples. Anal. Biochem., $190: 360$ - 365.

35. Rotruck, J.T.; Pope, A.L.; Ganther, H.E.; Swanson, A.B.; Hafeman, D.G. and Hoekstra, W.G. (1973): Selenium: Biochemical roles as a component of glutathione peroxidase. Science, 179: 588 590.

36. Johansson, L.H. and Borg, L.A.H. (1988): A spectrophotometric method for determination of catalase activity in small tissue samples. Anal. Biochem., 174 : 331-336.

37. Oyanagui, Y. (1984): Evaluation of assay methods and establishment of kit for superoxide dismutase. Anal. Biochem., 142: 290-296.

38. Milton, J.S.; Corbert, J.J. and Teer,P.M. (1986): Introduction to statistics $3^{\text {rd }}$ ed . D.C.Health and Company, Canada

39. Snedecor, G.W. and Cochran, W.G. (1982): Statistical Methods. $7^{\text {th }}$ ed. Iowa State University Press, Ames Iowa, USA. 
40. Moss, N.G.; Powell, S.L. and Falk, R.J. (1985): Intravenous cyclosporine activates afferent and efferent renal nerves and causes sodium retention in innervated kidneys in rats. Proc. Natl. Acad. Sci .USA, 82(23): 8222-8226.

41. Canafax, D.M. and Ascher, N.L. (1983): Cyclosporine immunosuppression. Clin. Pharm., 2:515-24.

42. Calne, R.Y.; Williams, R.and Lindop, M. (1981): Improved survival after orthotopic liver grafting. BMJ., 283 (1):115-8.

43. Oyer, P.E.; Stinson, E.B. and Jamieson, S. W. (1983): Cyclosporine in cardiac transplantation: a $2 \frac{1}{2}$ year followup. Transplant. Proc., 15(Suppl., 1):2546-52.

44. Gale, R.P.; Kay, H.E.M. and Rimm, A.A. (1982): Bonemarrow transplantation for acute leukemia in first remission. Lancet, 2: 1006-1009.

45. Merion, R.M.; White, D.J.G, Thiru S. (1984): Cyclosporine: five years' experience in cadaveric renal transplantation. N. Engl. J. Med., 310:148-154.

46. Stiller, C.R.; Laupacis, A.; Dupre, J. (1983): Cyclosporine for treatment of early type I diabetes: preliminary results. $\mathrm{N}$ Engl J Med., 308:1226-7.

47. Cohen, S.L.; Boner, G. and Rosenfeld, J.B. (1987): The mechanism of hyperuricemia in cyclosporine-treated renal transplant recipients. Transplant Proc., 19:1829-30.

48. Scott, J.P. and Higenbottam, T.W. (1988): Adverse reactions and interactions of cyclosporin. Med. Toxicol. Adverse Drug Exp., 3:107-27.

49. Gupta, S.; Keshavarzian, A. and Hodgson, H.J.F. (1984): Cyclosporin in ulcerative colitis. Lancet, 2:1277-1278.

50. Korstanje, M.J.; Bilo, H.J.G.and Stoof, T.J. (1992): Sustained renal function loss in psoriasis patients after withdrawal of low-dose cyclosporin therapy. Br. J. Dermatol., 127:501-4.

51. Grossman, R.M.; Chevret, S. and Abi-Rached, J. (1996): Long-term safety of cyclosporine in the treatment of psoriasis. Arch. Dermatol., 132:623-9.

52. Ameer, B.,Weintraub, R.A. (1997): Drug interactions with grapefruit juice. Clin. Pharmacokinet. , 33:103-21.

53. Pei, Y.; Scholey, J.W.and Katz, A. (1994): Chronic nephrotoxicity in psoriatic patients treated with low-dose cyclosporine. American Journal of Kidney Diseases, 23:528-36.

54. Feutren; G.; Friend, D.; Timonen, P. (1990): Predictive value of cyclosporin A level for efficacy or renal dysfunction in psoriasis. Br. J .Dermatol., 122(Suppl., 36):85-93.

55. Yee, G.C. and McGuire, T.R. (1990): Pharmacokinetic drug interactions with cyclosporin (Part II). Clin. Pharmacokinet. , 19:400-15.

56. Mervaala, E.M.; Pere, A.K.; Lindgren, L.; Laakso, J.; Teravainen, T.L.; Karjala, K.; Vapaatalo, H.; Ahonen, J. and Karppanen, H. (1997): Effects of dietary sodium and magnesium 
on cyclosporin A-induced hypertension and nephrotoxicity in spontaneously hypertensive rats. Hypertension, 29(3):822827.

57. Cheng, C.H.; Hsieh, C.L.; Shu, K.H.; Chen, Y.L. and Chen, H.C. (2002): Effect of calcium channel antagonist diltiazem and calcium ionophore A23187 on cyclosporine A-induced apoptosis of renal tubular cells. FEBS (Lett), 516(1-3):191-196.

58. McGrath, L.T.; Treacy, R.; McClean, E.and Brown, J.H. (1997): Oxidative stress in cyclosporin and azathioprine treated renal transplant patients. Clin. Chim. Acta.,264(1):1-12.

59. Satyanarayana, P.S. and Chopra, K.(2002): Oxidative stress-mediated renal dysfunction by cyclosporine $\mathrm{A}$ in rats: attenuation by trimethazidine. Ren Fail., 24(3):259-274.

60. De Nicola, L.;Thomson, S.C.; Wead, L.M.; Brown, M.R. and Gabbai, F.B. (1993): Arginine feeding modifies cyclosporine nephrotoxicity in rats. J .Clin. Invest. , 92(4):1859-1865.

61. Chen, J. ; Wanming, D.; Zhang, D. ; Liu, Q. and Kang, J. (2005): Water-soluble antioxidants improve the antioxidant and anticancer activity of low concentrations of curcumin in human leukemia cells. Pharmazie, 60(1):57-61.

62. Zhong, Z.; Arteel, G.E.; Connor, H.D.; Yin, M.; Frankenberg, M.V.; Stachlewitz, R.F.; Raleigh, J.A.; Mason, R.P. and Thurman, R.G.(1998): Cyclosporin A increases hypoxia and free radical production ;in rat kidneys: prevention by dietary glycine. Am. J. Physiol., 275(4 Pt 2):F595-604.

63. Knight, J.A.; Cheung, A.K.; Pieper, R.K. and Servilla, K. (1989): Increased urinary lipoperoxide levels in renal transplant patients. Ann. Clin. Lab. Sci., 19(4):238-241.

64. Lanese, D.M. and Conger, J.D. (1993): Effects of endothelin receptor antagonist on cyclosporine-induced vasoconstriction in isolated rat renal arterioles. J .Clin. Invest., 91(5):2144-2149.

65. Lanese, D.M.; Falk, S.A. and Conger, J.D. (1994): Sequential agonist activation and sitespecific mediation of acute cyclosporine constriction in rat renal arterioles. Transplantation. 58(12):1371-1378.

66. Lo Russo, A.; Passaquin, A.C.; Andre, P.; Skutella, M. and Ruegg, U.T. (1996): Effect of cyclosporin A and analogues on cytosolic calcium and vasoconstriction: possible lack of relationship to immunosuppressive activity. Br. J. Pharmacol., 118(4):885-892.

67. Avdonin, P.V.; Cottet-Maire, F.; Afanasjeva, G.V.; Loktionova, S.A.; Lhote, P. and Ruegg, U.T. (1999): Cyclosporine A up-regulates angiotensin II receptors and calcium responses in human vascular smooth muscle cells. Kidney Int ., 55(6):2407-2414.

68. Zhong, Z.; Connor, H.D.; Yin, M.; Moss. N.; Mason, R.P.; 
Bunzendahl, H.; Forman, D.T. and Thurman, R.G. (1999): Dietary glycine and renal denervation prevents cyclosporin A-induced hydroxyl radical production in rat kidney. Mol. Pharmacol ., 56(3):455-463.

69. Gottschalk, A.R.; Boise, L.H.; Thompson, C.B. and Quintans, J. (1994): Identification of immunosuppressant-induced apoptosis in a murine B-cell line and its prevention by bcl-x but not bcl-2. Proc Natl Acad Sci USA, 91:7350-7354.

70. Buttke, T.M. and Sandstrom, P.A. (1994): Oxidative stress as a mediator of apoptosis. Immunol., 15:7-10

71. Ueda, N. and Shah, S.V.(1992): Endonuclease-induced DNA damage and cell death in oxidant injury to renal tubular epithelial cells. J. Clin. Invest., 90:25932597.

72. Shoskes, D.A. (1998): Effect of bioflavonoids quercetin and curcumin on ischemic renal injury: a new class of renoprotective agents. Transplantation. 66(2):147-152.

73. Skrzydlewska, E.; Ostrowska, J.; Farbiszewski, R. and Michalak, K. (2002): Protective effect of green tea against lipid peroxidation in the rat liver, blood serum and the brain. Phytomedicine. 9(3):232-238.

74. Garcia-Cohen, E.C.; Marin, J. ; Diez-Picazo, L.D.; Baena, A.B.; Salaices, M. and RodriguezMartinez, M.A. (2000): Oxidative stress induced by tertbutyl hydroperoxide causes vasoconstriction in the aorta from hypertensive and aged rats: role of cyclooxygenase-2 isoform. J. Pharmacol. Exp. Ther., 293(1):75-81.

75. Rukkumani, R.; Sri Balasubashini, M. and Menon, V.P. (2003): Protective effects of curcumin and photo-irradiated curcumin on circulatory lipids and lipid peroxidation products in alcohol and polyunsaturated fatty acid-induced toxicity. Phytother Res .,17(8):925-929.

76. Somasundaram, S.; Edmund, N.A.; Moore, D.T.; Small, G.W.; Shi, Y.Y; Orlowski, R.Z. (2002): Dietary curcumin inhibits chemotherapy-induced apoptosis in models of human breast cancer. Cancer Res. 62(13):38683875.

77. Sreejayan, N. and Rao, M.N. (1996): Free radical scavenging activity of curcuminoids. Arzneimittelforschung. 46 (2): 169-171.

78. Sreejayan, N; Rao, M.N.(1997): Nitric oxide scavenging by curcuminoids. J. Pharm, Pharmacol ., 49(1):105-107.

79. Rao, C.V.; Rivenson, A.; Simi, B.and Reddy, B.S. (1995): Chemoprevention of colon carcinogenesis by dietary curcumin, a naturally occurring plant phenolic compound. Cancer. Res., 55(2):259-266.

80. Unnikrishnan, M.K. and Rao, M.N. (1995): Curcumin inhibits nitrogen dioxide induced oxidation of hemoglobin. Mol. Cell Biochem ., 146(1):35-37.

81. Ruby, A.J.; Kuttan, G.; Babu, K.D.; Rajasekharan, K.N. and Kuttan, R. (1995): Anti-tumor 
and antioxidant activity of natural curcuminoids. Cancer (Lett.,) 94(1):79-83.

82. Priyadarsini, K. I.; Maity, D. K; Naik, G. H.; Kumar, M. S.; Unnikrishnan, M. K.; Satav, J. G. and Mohan, H. (2003): Role of phenolic $\mathrm{OH}$ and methylene hydrogen on the free radical reactions and antioxidant activity of curcumin. Free Radic .Biol. Med ., 35(5):475-484.

83. Dawson, T.M.; Dawson, V.L. and Snyder, S.H. (1992): A novel neuronal messenger molecule in brain: the free radical, nitric oxide. Ann .Neurol, 32(3):297-311.
84. Amore,A.;Emancipator, S.N.; Cirina, P.; Conti, G.;Ricotti, E.; Bagheri, N.and Coppo, R. (2000): Nitric oxide mediates cyclosporine-induced apoptosis in cultured renal cells. Kidney Int., 57(4):1549-1559.

85. Chan, M.M.; Huang, H.I.; Fenton, M.R.and Fong, D. (1998): In vivo inhibition of nitric oxide synthase gene expression by curcumin, a cancer preventive natural product with antiinflammatory properties. Biochem. Pharmacol., 55(12): 1955-1962. 